\title{
Spontan bakteriyel peritonit: Etken ne? Olgu sunumu
}

\author{
Spontaneous bacterial peritonitis: What is the causative agent? A case report
}

\author{
(D) Feyzi BOSTAN ${ }^{1}$, DMüberra KAPLAN ÇAYIR ${ }^{1}$, DAyhan Hilmi ÇEKIN² \\ Sağlık Bilimleri Üniversitesi, Antalya Eğitim ve Araştırma Hastanesi, 'íç Hastalıkları Kliniği, 'ªastroenteroloji Kliniği, Antalya
}

\begin{abstract}
Spontan bakteriyel peritonit intra-abdominal cerrahi öyküsü olmaksızın asit sIvIsında bakteriyel enfeksiyon görülmesidir ve asitin ölümcül bir komplikasyonudur. Spontan bakteriyel peritonit tanısı genelde sirozlu hastada, karın ağrısı, hepatorenal sendrom gibi dekompanzasyon olduğunda ya da rutin yapılan parasentezde nötrofil sayısııın 250/ $\mathrm{mm}^{3}$ ve üzerinde olması ile konur. Sıkıkla etken mikroorganizmalar enterik gram negatif bakterilerdir. Tedaviye bu mikroorganizmalara yönelik ampirik olarak başlanır ve kültür sonucuna göre revize edilebilir. Listeria monocytogenes spontan bakteriyel peritonitin nadir görülen etkenidir. Gram pozitif, fakültatif anaerob basildir ve özellikle neonatallerde, yaşlı ve immünsuprese kişilerde enfeksiyona yol açar. Diğer enfeksiyonların genel bir bulgusu olan ateş, spontan bakteriyel peritonitli hastada genellikle görülmez. Biz bu yazımızda asit ve periferik ödem şikayetiyle yatırılan, kriptojenik karaciğer sirozu tanısı konulan, altmış yedi yaşında bayan hastada ampirik olarak tedavi edilirken karın ağrısı ve ateşi olması nedeniyle alınan asit sIVIsında Listeria monocytogenes üreyen vakamızı sunduk. Spontan bakteriyel peritonit ampirik olarak tedavi edilirken ateşi çıkan hastanın alınan asit kültüründe ve kan kültüründe Listeria monocytogenes üredi. Listeria monocytogenes'in nadir görülen bir patojen olduğu bilinmesine rağmen bizim vakamızda olduğu gibi yaş ve kronik hastalık gibi faktörler görülme sıklığını arttırabilir. Ampirik tedaviye yanıt vermeyen veya tedavi sırasında ateş gibi sistemik belirti gösteren spontan bakteriyel peritonitli hastalarda çok nadir olmasına rağmen Listeria monocytogenes akla gelmelidir.
\end{abstract}

Anahtar kelimeler: Listeria monocytogenes, spontan bakteriyel peritonit, siroz

\section{GíRiş}

Sirotik hastada asit görülmesi önemli bir mortalite ve morbidite nedenidir. Persistan asit genellikle dekompanse karaciğer hastalığının bir göstergesi veya sonucudur. Bu daha sonra enfekte olabilir ve spontan bakteriyel peritonite (SBP) neden olabilir. SBP, batın içi bir kaynağa dair kanıt olmaksızın asit sıvısında >250 polimorfonükleer (PMN) hücre/ $\mathrm{mm}^{3}$ varlığı olarak tanımlanır $(1,2)$. SBP'nin en yaygın nedeni Escherichia coli ve Klebsiella gibi gram negatif bakterilerdir. Bununla birlikte Candida, anaerob bakteriler ve Listeria monocytogenes kaynaklı SBP'ler de gösterilmiştir (3). Listeria türleri sporsuz gram pozitif

iletişim: Feyzi BOSTAN

Sağlık Bilimleri Üniversitesi Antalya Eğitim ve Araştırma Hastanesi, Dahiliye

Kliniği, Varlık Mah., Muratpaşa, Antalya

Tel: +90242 24940 00-3420 • E-mail: feyzi@dr.com
Spontaneous bacterial peritonitis is a bacterial infection in ascitic fluid without a history of intra-abdominal surgery and is a fatal complication of ascites. Spontaneous bacterial peritonitis is usually diagnosed when a cirrhotic patient has abdominal pain or when a patient with cirrhosis decompensates, such as hepatorenal syndrome, or when routine paracentesis is performed. The diagnosis is established when the neutrophil count is $\geq 250 / \mathrm{mm}^{3}$. The causative microorganisms are often enteric Gram-negative bacteria. Spontaneous bacterial peritonitis is treated empirically, and the treatment can be revised according to the culture result. Listeria monocytogenes is a rare cause of spontaneous bacterial peritonitis. It is a Gram-positive facultative anaerobe bacillus that causes infections, particularly in neonates, the elderly, and immunocompromised individuals. Fever, a common finding of other infections, is not usually seen in patients with spontaneous bacterial peritonitis. In this case report, we present a case of a 67-year-old female hospitalized with complaints of ascites and peripheral edema and who was diagnosed with cryptogenic liver cirrhosis. Listeria monocytogenes grew in ascitic fluid recovered during empirical treatment due to fever. While the spontaneous bacterial peritonitis was being treated empirically, Listeria monocytogenes grew in ascites and blood cultures of the patient, who developed fever and recovered after a change in treatment. Although Listeria monocytogenes is a rare pathogen, factors, such as age and chronic disease, may increase its incidence, as in our case. Listeria monocytogenes should be considered in patients with spontaneous bacterial peritonitis who do not respond to empirical treatment or who show systemic symptoms, such as fever, during treatment.

Key words: Listeria monocytogenes, spontaneous bacterial peritonitis, cirrhosis

basillerdir ve fakültatif anaerobdurlar. Çevresel kaynaklardan veya memeli dışkılarından bulaşırlar. Özellikle yenidoğanlar, yaşlılar ve immünsuprese kişilerde menenjit, septisemi, neonatal enfeksiyonlar gibi tablolara yol açabilmektedirler (4). Bu yazımızda kriptojenik karaciğer sirozu tanısı konulan, kan ve asit kültürlerinde Listeria monocytogenes üreyen altmış yedi yaşındaki bayan hastayı sunuyoruz. Türkiye'de Listeria monocytogenes'e bağlı yayınlanan ilk SBP vakası olması dolayısıyla da Türkiye'de SBP tedavisi yapan hekimlere kaynak olacağını düşünüyoruz.

Bostan F, Kaplan Çayır M, Çekin AH, Spontaneous bacterial peritonitis: What is the causative agent? A case report. The Turkish Journal of Academic Gastroenterology 2021;20:59-61. DOI: 10.17941/agd.928433

Geliş Tarihi: 24.11.2020 • Kabul Tarihi: 17.12.2020 


\section{OLGU SUNUMU}

Altmış yedi yaşında bayan hasta, karın ve bacaklarda şişlik şikayeti ile gastroenteroloji polikliniğine başvurdu. Batında asit saptanan hasta asit etiyolojisinin tetkik edilmesi için servise yatırıldı. Kronik hastalık olarak hipertansiyon ve Diyabetes Mellitusu mevcuttu. Hastanın vital bulgularında; tansiyon: 150/90 mm/Hg, nabız:100/dk, $\mathrm{SpO}_{2}$ : 95 idi. Fizik muayenede solunum sesleri bibaziler azalmış, batında grade 3 asit ve bilateral ++/++ pretibial ödem mevcuttu. Diğer sistem muayeneleri doğaldı. Yapılan asit incelemesinde portal tipte asit olduğu görüldü. Hastada asite neden olan durumun karaciğer sirozu olduğu görüldü. Sirozun etiyolojisine yönelik yapılan viral serolojik testler, ekokardiyografi, otoantikor testleri, demir ve bakıra yönelik kan ve idrar tetkikleri negatif geldi. Alkol kullanım öyküsü olmayan ve görüntülemelerde hepatosteatoz bulgusu bulunmayan hasta kriptojenik karaciğer sirozu olarak kabul edildi. Model for End-Stage Liver Disease (MELD) skoru 11 olarak hesaplandı. Başvuru sırasında tanısal amaçlı yapılan parasentezde SBP olmayan hastanın yatışııın 5. gününde karın ağrısı ve ateş nedeniyle tekrarlanan parasentezinde asitte nötrofil sayısı 10493/ mm3 geldi. SBP açısından yapılan batın bilgisayarlı tomografide ve cerrahi konsültasyonda SBP düşündürecek bulguya rastlanmadı. Hastaya ampirik olarak intravenöz yoldan sefotaksim $3 \times 2 \mathrm{~g}$ başlandı. 48. saatte alınan asitte nötrofil sayısı $5861 / \mathrm{mm}^{3}$ gelmesi üzerine tedaviye devam edildi. Sefotaksim tedavisinin 5. gününde hastanın ateşi oldu. Yeniden yapılan asit hücre sayımında nötrofil sayısı $8256 / \mathrm{mm}^{3}$ geldi. Geriye dönük olarak alınmış olan asit ve kan kültürleri incelendiğinde SBP tanısı konulduğu, sefoaksim tedavisinin başlanmadan önce alınan asit ve kültüründe Listeria monocytogenes ürediği görüldü. Tedavi antibiyograma uygun olarak ampisilin $6 \times 2 \mathrm{~g}$ olarak değiştirildi. Kliniği düzelen hastada, ampisilin tedavisinin 48. saatinde alınan asit ve kan kültürlerinde üreme olmadı. Tedavisi 14 güne tamamlanan hasta taburcu edildi. Hastadan bilgilendirilmiş onam formu imzalatılarak onam alınmıştır.

\section{TARTIŞMA}

SBP; siroz hastalarında asitlerde ortaya çıkan enfeksiyondur ve sıkıkla bağırsak kaynaklı bakterilerden (enterik gram negatif) kaynaklanır (2). Listeria monocytogenes daha nadir bir etkendir. Listeria monocytogenes, fakülta- tif anaerobic, gram pozitif bir basildir ve bulaş kontamine gıda veya hayvansal ürünlerden fekal-oral yolla gerçekleşir (5). Hafif grip benzeri hastalıktan menenjit, meningoensefalit ve septisemiye kadar geniş klinik semptomlara neden olabilir $(5,6)$. Genellikle neonatallerde, yaşlılarda ve hücresel bağışıklı̆ı baskılanmış kişilerde enfeksiyona yol açar (5).

Siroz; spesifik siroz-lişkili immün disfonksiyona yol açar (7). Siroz-lişkili immün disfonksiyon, sirozda meydana gelen hem immün yetmezlik hem de sistemik inflamasyonu ifade eder (8). Bizim olgumuzda da hastamızın hem siroz olması hem de yaş faktörü nedeniyle immünite zayıflığı göze çarpmaktadır.

SBP'de ampirik tedaviyi geciktirmemek önemlidir. Genellikle ilk basamakta 3. kuşak sefalosporinler başlanır (1). Ampirik tedavi; gram pozitif kokları, ilaca dirençli bakterileri ve duyarlı mikroorganizmaları kapsamalıdır (2). Kartali ve ark. 71 yaş non-alkolik karaciğer sirozu olan kadın hastada Listeria monocytogenes'e bağlı SBP olgusu bildirmişlerdir (6). Çalışmada Listeria monocytogenes'in penisilinler, birinci ve ikinci kuşak sefalosporinler, makrolidler, aminoglikozidler, tetrasiklinler, trimetoprim-sülfametoksazol, karbapenemler, rifampisin ve kloramfenikol gibi çok sayıda antibiyotiğe duyarlı ancak geniş spektrumlu sefalospoinlere doğal dirençli olduğunun gösterilmesi dikkati çekmektedir. Listeria monocytogenes'e bağlı SBP'de tedavi ile ilgili net bir süre belirtilmese de ortalama tedavi süresi genellikle 10-14 gündür (9). Bizim olgumuzda da 14 gün ampisilin tedavisi verilmiştir.

Sonuç olarak; standart tedavilere yanıt vermeyen ve ateş gibi sistemik semptomları gelişen SBP'li siroz hastalarında, Listeria monocytogenes peritonit nedeni olarak akla gelmelidir. SBP'te tedaviyi geciktirmemek mortaliteyi azaltmada önemlidir, ancak Listeria monocytogenes'in 3. kuşak sefalosporinlere dirençli olduğu unutulmamalıdır. Ampirik tedavi başlanırken Listeria monocytogenes gibi nadir görülen mikroorganizmaların da akla getirilmesinin yararlı olacağı düşüncesindeyiz. Ampirik tedaviye yanıt vermeyen veya tedavi sırasında ateş gibi sistemik belirti gösteren SBP'li hastalarda çok nadir olmasına rağmen Listeria monocytogenes akla gelmelidir.

Bu vaka sunumumuzda Helsinki Deklarasyonuna uyulmuştur ve herhangi bir çıkar çatışması ve finansal katkı yoktur. 


\section{KAYNAKLAR}

1. EASL Clinical Practice Guidelines for the management of patients with decompensated cirrhosis. J Hepatol 2018;69:406-60.

2. Kowdley K. Spontaneous bacterial peritonitis. Gastroenterol Hepatol (NY) 2015;11:70-2.

3. Hutchison JG, Runyon BA. Spontaneous bacterial peritonitis. In Surawicz CM, Owen RL, editors. Gastrointestinal and Hepatic Infections. Philadelphia, PA, USA: WB Saunders; 1995.

4. Ayaydın Z, Aktar GS, Onur AR, ve ark. Seyrek izole edilen bir etken: Listeria monocytogenes. Türk Mikrobiyol Cem Derg 2017;47:14650.

5. Yecies T, Inagami S. Spontaneous bacterial peritonitis caused by Listeria monocytogenes associated with ascitic fluid lymphocytosis: A case report and review of current empiric therapy. Case Reports in Hepatol 2013;2013:832457.
6. Kartali G, Tsivitanidou M, Nikolaidis N, et al. Spontaneous bacterial peritonitis caused by Listeria monocytogenes. Ann Gastroenterol 2001;14:63-4.

7. Shaikh B, Pathak R, Mainali NR, Gupta S. Listeria monocytogenes as a cause of spontaneous bacterial peritonitis: a rare entity. J Community Hosp Intern Med Perspect 2015;5:26153.

8. Albillos A, Lario M, Alvarez-mon M. Cirrhosis-associated immune dysfunction: Distinctive features and clinical relevance. J Hepatol 2014;61:1385-96.

9. Cardoso C, Cremers I, Oliveira AP. Spontaneous bacterial peritonitis caused by Listeria monocytogenes: a case report and literature review. Ann Hepatol 2012;11:955-7. 